\title{
IMPLEMENTASI HUKUM TERHADAP TENAGA KERJA PEREMPUAN YANG BEKERJA PADA MALAM HARI (STUDI PADA PEKERJA HOTEL LEE BANDAR JAYA LAMPUNG TENGAH)
}

\section{LEGAL IMPLEMENTATION ON WOMEN WORKERS WHO WORK AT NIGHT (STUDY ON HOTEL WORKERS LEE BANDAR JAYA LAMPUNG CENTRAL)}

\author{
Irhammudin $^{1^{*}}$, Ibrahim Fikma Edrisy ${ }^{2}$ \\ Universitas Muhammadiyah Kotabumi \\ Jln. Hasan Kepala Ratu No.1052 Sindangsari, Kotabumi, Lampung Utara, \\ Provinsi Lampung, 34517 \\ Email: irhammudin.umko@gmail.com*
}

$\begin{array}{ll}\text { Submission } & : \text { 17 Januari } 2022 \\ \text { Accepted } & : \text { 25 Januari } 2022 \\ \text { Publish } & : \text { 31 Januari } 2022\end{array}$

\begin{abstract}
Legal protection for workers is the fulfillment of basic rights inherent and protected by the constitution as regulated in Article 27 Paragraph (2) of the 1945 Constitution. Article 33 Paragraph (1) of the 1945 Constitution also states that the economy is structured as a joint effort of kinship. Violation of basic rights protected by the constitution is a violation of human rights. The sovereignty of a country is stated in the constitution which regulates the basics of the state and guarantees the rights and obligations of its citizens. Law Number 13 of 2003 concerning Manpower is one solution in protecting workers and employers regarding the rights and obligations of each party. Labor protection is regulated more clearly in Article 67 to Article 101 covering the protection of workers with disabilities, children, women, working hours, occupational safety and health, wages and welfare. In principle, the Manpower Law protects and regulates the rights and obligations of both workers and employers. In its implementation, various kinds of problems may arise that can harm the workforce itself, especially with regard to legal protection for female workers. Therefore, this study wants to reveal the form of legal protection that should be received by female workers who work at night. especially with regard to the legal protection of female workers. Therefore, this study wants to reveal the form of legal protection that should be received by female workers who work at night. especially with regard to the legal protection of female workers. Therefore, this study wants to reveal the form of legal protection that should be received by female workers who work at night.
\end{abstract}

Keywords: Legal Protection, Labor, Women 


\begin{abstract}
Abstrak
Perlindungan hukum terhadap pekerja merupakan pemenuhan hak dasar yang melekat dan dilindungi oleh konstitusi sebagaimana yang diatur didalam Pasal 27 Ayat (2) UUD 1945. Di dalam Pasal 33 Ayat (1) UUD 1945 juga dinyatakan bahwa perekonomian disusun sebagai usaha bersama atas kekeluargaan. Pelanggaran terhadap hak dasar yang dilindungi konstitusi merupakan pelanggaran hak asasi manusia. Kedaulatan sebuah negara dituangkan dalam konstitusi yang mengatur dasar-dasar bernegara dan jaminan atas hak dan kewajiban warga negaranya. UU Nomor 13 Tahun 2003 tentang Ketenagakerjaan merupakan salah satu solusi dalam perlindungan buruh maupun majikan tentang hak dan kewajiban masing-masing pihak. Perlindungan buruh diatur lebih jelas di dalam Pasal 67 s.d. Pasal 101 meliputi perlindungan buruh penyandang cacat, anak, perempuan, waktu kerja, keselamatan dan kesehatan kerja, pengupahan dan kesejahteraan. Pada prinsipnya, UU Ketenagakerjaan melindungi dan mengatur hak dan kewajiban bagi para tenaga kerja maupun para pengusaha. Dalam pelaksanaannya, dapat saja timbul berbagai macam masalah yang dapat merugikan pihak tenaga kerja itu sendiri, terutama yang berkenaan dengan perlindungan hukum terhadap tenaga kerja perempuan. Oleh karena itu, penelitian ini ingin mengungkap bentuk perlindungan hukum yang seharusnya diterima oleh tenaga kerja perempuan yang bekerja pada malam hari.
\end{abstract}

\title{
Kata Kunci: Perlindungan Hukum, Tenaga Kerja, Wanita
}

\section{A. Pendahuluan}

Pemerintah Indonesia sedang menggalakkan pembangunan di semua lini, salah satunya pembangunan ketenagakerjaan yang merupakan bagian tak terpisahkan dari pembangunan nasional berlandaskan Pancasila dan UUD 1945. Perlindungan hukum terhadap pekerja merupakan pemenuhan hak dasar yang melekat dan dilindungi oleh konstitusi sebagaimana yang diatur didalam Pasal 27 Ayat (2) UUD 1945 yang berbunyi, "tiap-tiap warga Negara berhak atas pekerjaan dan penghidupan yang layak bagi kemanusiaan”. Pasal 33 Ayat (1) juga menyatakan bahwa "Perekonomian disusun sebagai usaha bersama atas kekeluargaan". Pentingnya pengakuan hak asasi bagi setiap manusia harus senantiasa dijaga melalui berbagai hukum positif di Indonesia. Adanya pengakuan terhadap eksistensi hak asasi manusia membawa dampak pentingnya 
mengupayakan perlindungan terhadap hak-hak tersebut untuk menghindari potensi kerugian yang dapat terjadi pada manusia itu sendiri. ${ }^{1}$

Pelanggaran terhadap hak dasar yang dilindungi konstitusi merupakan pelanggaran hak asasi manusia. Kedaulatan sebuah negara dituangkan dalam konstitusi yang mengatur dasar-dasar bernegara dan jaminan atas hak dan kewajiban warga negaranya. Pekerja/buruh merupakan bagian dari tenaga kerja yaitu tenaga kerja yang telah melakukan kerja, baik bekerja untuk diri sendiri maupun bekerja dalam hubungan kerja atau di bawah perintah pemberi kerja (bisa perseorang, pengusaha, badan hukum atau badan lainnya) dan atas jasanya dalam bekerja yang bersangkutan menerima upah atau imbalan dalam bentuk lain. ${ }^{2}$

Demi memenuhi kebutuhan hidup yang layak, sebagian wanita memilih bekerja keras agar kebutuhan mereka tercukupi. Kondisi ini membuat mayoritas lapangan pekerjaan di tingkat organisasi menjadi rendah dan tidak harus membutuhkan keterampilan khusus sehingga memberikan peluang yang besar bagi tenaga kerja wanita. ${ }^{3}$ Bagi pekerja/buruh perempuan yang belum berkeluarga masalah yang timbul berbeda dengan yang sudah berkeluarga yang sifatnya lebih subyektif, meski secara umum dari kondisi objektif tidak ada perbedaanperbedaan. Perhatian yang benar bagi pemerintah dan masyarakat terhadap pekerja/buruh perempuan terlihat pada beberapa peraturan-peraturan yang memberikan kelonggaran-kelonggaran maupun larangan-larangan yang menyangkut kedirian seorang perempuan secara umum seperti cuti hamil, kerja pada malam hari dan sebagainya. ${ }^{4}$

${ }^{1}$ Ngajulu Petrus, "Perlindungan Hukum Terhadap Tenaga Kerja Wanita Yang Bekerja Pada Malam Hari Di PT Swara Indah Riau Berdasarkan Undang-Undang Nomor 13 Tahun 2003 Tentang Ketenagakerjaan,” JOM Fakultas Hukum III, No. 2 (2016): 1-15.

${ }^{2}$ Ni Wayan Mega Jayantari, "Perlindungan Hukum Terhadap Pekerja Perempuan Pada Malam Hari Di Minimarket Alfamart Mataram (Studi Berdasarkan Undang-Undang No.13 Tahun 2003 Tentang Ketenagakerjaan" (Universitas Mataram, 2013), hlm. 4.

${ }^{3}$ Rizki Ramadhan, "Implementasi Perlindungan Hukum Terhadap Tenaga Kerja Wanita Yang Bekerja Di SPBU Pada Malam Hari Ditinjau Dari Pasal 76 Undang-Undang Ketenagakerjaan (Studi SPBU Kabupaten Trenggalek)" (Universitas Muhammadiyah Malang, 2019), hlm. 1.

${ }^{4}$ Jayantari, hlm. 4-5. 
Dengan semakin berkembangnya zaman dan biaya kebutuhan yang terus meningkat, menimbulkan banyak wanita yang tertarik untuk terjun ke dunia pekerjaan. Munculnya industri-industri baru, menimbulkan banyak peluang bagi angkatan kerja. Tuntutan ekonomi yang mendesak dan adanya kesempatan untuk bekerja telah memberikan daya tarik yang kuat bagi tenaga kerja wanita. Tidak hanya menarik bagi wanita yang masuk pada golongan angkatan kerja, tetapi sering juga wanita yang belum dewasa yang selayaknya masih harus belajar di sekolah juga ikut tertarik untuk masuk ke dunia kerja. ${ }^{5}$

Bagi tenaga kerja wanita yang belum berkeluarga masalah yang timbul berada dengan yang sudah berkeluarga. Perhatian pemerintah dan masyarakat terhadap tenaga kerja terlihat pada beberapa peraturan-peraturan yang memberikan kelonggaran-kelonggaran maupun larangan-larangan yang menyangkut diri seseorang wanita secara umum seperti cuti hamil, kerja pada malam hari dan sebagainya.

Undang-Undang Nomor 13 Tahun 2003 tentang ketenagakerjaan merupakan salah satu solusi dalam perlindungan buruh maupun majikan tentang hak dan kewajiban masing-masing pihak. Perlindungan buruh diatur di dalam Undang-Undang Pasal 67 s.d. Pasal 101 meliputi perlindungan buruh penyandang cacat, anak, perempuan, waktu kerja, keselamatan dan kesehatan kerja, pengupahan dan kesejahteraan. Undang-Undang Ketenagakerjaan melindungi dan mengatur hak dan kewajiban bagi para tenaga kerja maupun para pengusaha.

Masih banyak pekerja perempuan di beberapa perusahaan yang belum terakomodir perlindungan hukumnya. Padahal dalam Kepermentas RI No.Kep.224/Men/2003 telah dicantumkan hak-hak para pekerja wanita yang bekerja di malam hari untuk mendapatkan fasilitas tertentu yang harus disediakan oleh perusahaan. ${ }^{6}$ Begitu juga Pelaksanaan hubungan kerja antara tenaga kerja

\footnotetext{
${ }^{5}$ Prisca Oktaviani, "Perlindungan Pekerja Perempuan Berdasarkan Undang-Undang Nomor 13 Tahun 2003 Tentang Ketenagakerjaan” (Lampung, 2013), hlm. 2.

${ }^{6}$ Dhea Yulianti, "Pelaksanaan Hak-Hak Normatif Terhadap Pekerja/Buruh Perempuan Yang Bekerja Di Malam Hari Dihubungkan Dengan Keputusan Menteri Tenaga Kerja Dan Transmigrasi Republik Indonesia Nomor: Kep.224/Men/2003 Tentang Kewajiban Pengusaha Yang Mempekerjakan Pekerja/B” (Universitas Islam Negeri Sunan Gunung Djati Bandung, 2021);
} 
antara pekerja wanita dan Hotel Mandarin Lee Bandar Jaya Lampung Tengah dapat saja timbul berbagai macam masalah yang dapat merugikan pihak tenaga kerja itu sendiri, terutama yang berkenaan dengan perlindungan hokum terhadap tenaga kerja perempuan. Oleh karena itu penelitian ini ingin mengungkap bentuk perlindungan hukum yang seharusnya diterima oleh tenaga kerja perempuan yang bekerja pada malam hari.

Pendekatan penelitian yang dilakukan peneliti dalam penulisan ini yaitu pendekatan kualitatif dalam penelitian hukum empiris (prilaku hukum di masyarakat). Pendekatan kualitatif yaitu suatu cara analisis hasil penelitian yang menghasilkan data deskritif analisis, yaitu data yang dinyatakan oleh responden secara tertulis ataupun lisan serta juga tingkah laku yang nyata, yang diteliti dan dipelajari sebagai suatu yang utuh. Dalam penelitian ini penulis menggunakan pendekatan masalah secara empiris, yaitu pendekatan yang dilakukan dengan melihat serta mengamati apa yang terjadi di lapangan, penerapan peraturanperaturan tersebut dalam prakteknya dalam masyarakat. ${ }^{7}$

\section{B. Hasil Penelitian dan Pembahasan}

\section{Implementasi Hukum terhadap Tenaga Kerja Perempuan yang} Bekerja pada Malam Hari di Hotel Mandarin Lee Bandar Jaya

\section{Lampung Tengah}

Perlindungan kerja bertujuan untuk menjamin berlangsungnya sistem hubungan kerja tanpa disertai adanya tekanan dari pihak yang kuat kepada pihak yang lemah. Untuk itu pengusaha wajib melaksanakan ketentuan perlindungan tersebut sesuai dengan peraturan perundang-undangan yang berlaku. Lingkup perlindugan terhadap pekerja/buruh menurut Undang-Undang Nomor 13 Tahun 2003, meliputi:

Kanyaka Prajnaparamita, "Perlindungan Hukum Terhadap Tenaga Kerja Wanita Di Indomaret Kota Pekanbaru Berdasarkan Undang-Undang Nomor 13 Tahun 2003 Tentang Ketenagakerjaan,” Adminitrative Law \& Governance Journal 2, No. 1 (2019): 34-46; Hj. Erwien Adisiswanto, "Perlindungan Terhadap Tenaga Kerja Wanita Yang Bekerja Pada Malam Hari Di Perusahaan," IUS 3, No. 01 (2015): 69-75.

\footnotetext{
${ }^{7}$ Peter Mahmud Marzuki, Penelitian Hukum, Cet. 7 (Jakarta: Kencana, 2011), hlm. 93.
} 
1) Perlindungan atas hak-hak dasar pekerja/buruhuntuk berunding dengan pengusaha;

2) Perlindungan keselamatan dan kerja;

3) Perlindungan khusus bagi pekerja/buruh perempuan, anak, dan penyandang cacat;

4) Perlindungan tentang upah, kesejahteraan, jaminan sosial tenaga kerja. ${ }^{8}$

Menurut Zaeni Asyhadie bahwa jenis perlindungan tenaga kerja dibagi menjadi 3 (tiga) macam, yaitu: ${ }^{9}$

1) Perlindungan ekonomis; Perlindungan tenaga kerja dalam bentuk penghasilan yang cukup, termasuk apabila tenaga kerja tidak mampu bekerja di luar kehendaknya.

2) Perlindungan social; Perlindungan tenaga kerja dalam bentuk jaminan kesehatan kerja, kebebasan berserikat, dan perlindungan hak untuk berorganisasi.

3) Perlindungan teknis; Perlindungan tenaga kerja dalam bentuk keamanan dan keselamatan kerja.

Perlindungan yang sifatnya khusus untuk tenaga kerja perempuan antara lain:

a. Perlindungan Jam Kerja

Pekerja/buruh perempuan yang berumur kurang dari 18 (delapan belas) tahun dilarang dipekerjakan antara pukul 23.00 sampai dengan pukul 07.00 (Pasal 76 ayat 1). Selanjutnya disebutkan Pengusaha dilarang mempekerjakan pekerja/buruh perempuan hamil yang menurut keterangan dokter berbahaya bagi kesehatan dan keselamatan kandungannya maupun dirinya apabila bekerja antara pukul 23.00 sampai dengan pukul 07.00. pengusaha yang mempekerjakan pekerja/buruh perempuan antara pukul 23.00 s.d. pukul 07.00 wajib:

1) Memberikan makanan dan minuman bergizi; dan

\footnotetext{
${ }^{8}$ Jayantari, "Perlindungan Hukum Terhadap Pekerja Perempuan Pada Malam Hari Di Minimarket Alfamart Mataram (Studi Berdasarkan Undang-Undang No.13 Tahun 2003 Tentang Ketenagakerjaan", hlm. 7.

${ }^{9}$ Zaeni Asyahadie, Hukum Kerja (Jakarta: PT. Rajagrafindo Persada, 2007), hlm. 78.
} 
2) Menjaga kesusilaan dan keamanan selama di tempat kerja

Pengusaha wajib menyediakan angkutan antar jemput bagi pekerja/buruh perempuan yang berangkat dan pulang bekerja antara pukul 23.00 sampai dengan pukul 05.00 (Pasal 76 ayat 4). ${ }^{10}$ Berdasar peraturan perundang-undangan pada prinsipnya tenaga kerja perempuan dilarang untuk bekerja pada malam hari, akan tetapi mengingat berbagai alasan, maka pekerja/buruh perempuan diizinkan untuk bekerja pada malam hari antara lain karena adanya alasan sosial, teknis dan alasan ekonomis.

Ketentuan yang mengatur kerja malam pekerja/buruh perempuan pada Pasal 7 ayat (1) Undang-Undang Nomor 12 Tahun 1984 menetapkan bahwa: "Orang wanita tidak boleh menjalankan pekerjaan pada malam hari, kecuali jikalau pekerjaan itu menurut sifat, tempat, dan keadaan seharusnya dijalankan oleh wanita." Tata cara mempekerjakan pekerja/buruh perempan pada malam hari telah dikeluarkan dengan Peraturan Menteri Tenaga Kerja RI Nomor Per04/MEN/1989 tentang tata cara mempekerjakan pekerja/buruh wanita pada malam hari yaitu:

1) Harus ada izin dari Depnaker setempat dengan syarat yang harus dipenuhi, misalnya, mutu produksi harus lebih baik bila mempekerjakan wanita.

2) Pengusaha harus menjaga keselamatan

3) Kesehatan dan kesusilaan (tidak boleh mempekerjakan wanita dalam keadaan hamil ada angkutan antar jemput dan sebagainya)

4) Penyediaan makanan ringan, ada izin dari orang tua atau suami, dan lain-lain. $^{11}$

Pengaturan buruh atau pekerja perempuan dalam Undang-Undang Nomor 13 Tahun 2003 telah banyak mengalami perubahan dari ketentuan sebelumnya yang melarang perempuan dipekerjakan pada malam hari, kecuali karena sifatnya

${ }^{10}$ Lalu Husni, Pengantar Hukum Ketenagakerjaan Indonesia (Jakarta: PT. Rajagrafindo Persada, 2007), hlm. 116-117.

${ }^{11}$ Jayantari, "Perlindungan Hukum Terhadap Pekerja Perempuan Pada Malam Hari Di Minimarket Alfamart Mataram (Studi Berdasarkan Undang-Undang No.13 Tahun 2003 Tentang Ketenagakerjaan", hlm. 10. 
pekerjaan tersebut harus dikerjakan oleh wanita dengan meminta izin instansi yang bertanggungjawab dibidang ketenagakerjaan. ${ }^{12}$

b. Perlindungan yang bersifat protektif

Pekerja atau buruh perempuan merupakan kelompok yang karena kodratnya mempunyai karakteristik tertentu yang mendapat perhatian, oleh karena itu dalam beberapa hal terhadap pekerja/buruh perempuan ini diberlakukan peraturan khusus yang menyangkut perlindungan pekerja/buruh perempuan, mencakup larangan kerja pada malam hari, larangan melakukan pekerjaan yang membahayakan kesehatan, kesusilaan perempuan. Bentuk-bentuk perlindungan tersebut berupa:

\section{1) Peraturan Cuti Haid}

Jika dalam masa haid merasakan sakit dan memberitahukan kepada pengusaha, tidak wajib bekerja pada hari pertama dan kedua pada waktu haid (Pasal 81 ayat 1 UU Nomor 13 Tahun 2003). Pelaksanaan ketentuan ini diatur dalam perjanjian kerja, peraturan perusahaan, atau perjanjian kerja bersama.

Bagi wanita yang normal dan sehat, pada usia tertentu akan mengalami haid, dalam prakteknya banyak wanita yang sedang dalam masa haid tetapi tetap bekerja tanpa gangguan apapun. Tetapi kalau keadaan fisiknya tidak memungkinkan sehingga yang bersangkutan tidak dapat melakukan pekerjaan tersebut. Hal ini diatur dalam Undang-Undang Nomor 1 Tahun 1951 tentang Pernyataan Berlakunya Undang-Undang Nomor 12 Tahun 1948 Tentang Kerja Terkait Cuti.

Pasal 13 Undang-Undang Nomor 12 Tahun 1948 menentukan bahwa buruh wanita tidak boleh diwajibkan bekerja bekerja pada hari pertama dan hari kedua waktu haid. Tidak boleh diwajibkan berarti dia boleh bekerja, tapi juga boleh tidak, terserah kepada buruh wanita itu sendiri. Untuk itu si buruh wanita harus memberitahukan sendiri keadaannya itu kepada majikan, karena majikan tidak mengetahui keadaan si buruh itu sendiri.

\footnotetext{
${ }^{12}$ Husni, Pengantar Hukum Ketenagakerjaan Indonesia, hlm. 117.
} 
Peraturan Pemerintah Nomor 7 Tahun 1948 mengatur bahwa buruh wanita yang hendak menggunakan haknya mengambil cuti haid, berkewajiban menyampaikan surat permohonan istirahat pada majikan 10 hari sebelumnya.

2) Peraturan Cuti Hamil/ Cuti Bersalin/ Cuti Keguguran

Pekerja/buruh perempuan berhak memperoleh istirahat selama 1,5 (satu setengah) bulan sebelum saatnya melahirkan anak dan 1,5 (satu setengah) bulan sesudah melahirkan menurut perhitungan dokter kandungan atau bidan (Pasal 82 ayat 1 Undang-Undang Nomor 13 Tahun 2003). ${ }^{13}$

Pekerja/buruh perempuan yang mengalami keguguran kandungan berhak memperoleh istirahat 1,5 (satu setengah) bulan atau sesuai dengan surat keterangan dokter atau bidan (Pasal 82 ayat 2 Undang-Undang Nomor 13 Tahun 2003).

3) Kesempatan Menyusui Anak pada Waktu Jam Kerja

Pekerja/buruh perempuan yang anaknya masih menyusui harus diberi kesempatan sepatutnya untuk menyusui anaknya jika hal itu harus dilakukan selama waktu kerja.

Di dalam penjelasan Pasal 13 ayat (4) ditentukan bahwa dipikirkan oleh pemerintah kemungkinan mengadakan tempat penitipan anak. Kesempatan sepatutnya adalah lamanya waktu yang diberikan kepada pekerja/buruh perempuan untuk menyusui bayinya dengan memperhatikan tersedianya tempat yang sesuai dengan kondisi dan kemampuan perusahaan yang diatur dalam peraturan perusahaan atau perjanjian kerja bersama.

Pada Pasal 83 Undang-Undang Nomor 13 Tahun 2003 tentang Ketenagakerjaan mengatur tentang masalah ibu menyusui. Pemberian kesempatan pada pekerja wanita yang anaknya masih membutuhkan ASI untuk menyusui anaknya hanya efektif untuk yang lokasinya dekat dengan perusahaan.

4) Penghapusan Perbedaan Perlakuan terhadap Pekerja/Buruh Perempuan

\footnotetext{
${ }^{13}$ Husni.
} 
Peningkatan perlindungan bagi pekerja/buruh perempuan dapat dilihat pula dengan adanya beberapa ketentuan yang menghapuskan adanya perbedaan perlakuan terhadap pekerja/buruh perempuan.

Peningkatan perlindungan bagi tenaga kerja wanita, dapat dilihat pula dengan adanya beberapa ketentuan yang menghapuskan adanya perbedaan perlakuan terhadap tenaga kerja wanita. Adapun ketentuan tersebut adalah :

a) UU Nomor 80 tahun 1957 tentang ratifikasi konvensi ILO Nomor 100 Tahun 1954 mengenai upah yang sama antara laki-laki dan wanita untuk pekerjaan yang sama nilainya. Dalam prakteknya banyak sekali keluhan dari para pekerja wanita tersebut, misalnya :

- Tidak diberi kesempatan untuk mendapatkan pendidikan tambahan atas beban perusahaan

- Adanya diskriminasi atas pengupahan yang sama untuk masa kerja yang sama dan pekerjaan yang sama nilainya, dan sebagainya.

b) Peraturan Pemerintah Nomor 8 Tahun 1981 tentang perlindungan upah yang menyatakan adanya pemberian sanksi terhadap pelanggaran ketentuan yang telah ditetapkan tersebut.

c) Peraturan Menteri Tenaga Kerja Nomor per. 04/MEN/ 1989 tentang larangan PHK bagi tenga kerja wanita karena hamil atau melahirkan. Peraturan Menteri ini memuat bahwa pengusaha tidak boleh mengurangi hak hak tenaga kerja wanita yang karena hamil dan karena fisik dan jenis pekerjaan tersebut tidak memungkinkan diikerjakan olehnya. Artinya walaupun pekerja tersebut cuti dan tugasanya dialihkan kepada orang lain, namun haknya untuk mendapatkan upah tetap tiap bulan dan jika ia sudah dapat bekerja lagi maka upah tersebut harus diterima kembali. Apabila perusahaan tidak memungkinkan untuk melaksanakan peraturan tersebut. Pengusaha wajib memberikan cuti diluar tanggungan perusahaan sampai timbul hak cuti hamil seperti yang telah ditetapkan oleh pasal 13 Undang Undang Nomor 1 Tahun 1951 apabila perusahaan melanggar ketentuan yang telah disebutkan diatas pengusaha dapat diancam atau denda setinggi tingginya seratus 
ribu rupiah sesuai dengan pasal 17 Undang Undang Nomor 14 Tahun 1969 tentang ketentuan ketentuan pokok mengenai tenaga kerja pada pasal 6 Peraturan Menteri Nomor 03/MEN/1989. ${ }^{14}$

5) Jaminan Sosial dan Pengupahan

Agar para pekerja dapat menjalankan pekerjaanya dengan semangat dan bergairah, masalah jaminan sosial dan pengupahan diperlukan oleh perusahaan. Jaminan sosial yang dimaksud antara lain jaminan sakit, hari tua, jaminan kesehatan, jaminan perumahan, jaminan kematian dan sebagainya. Mengenai jaminan sosial ini sudah diatur secara normatif dalam perundangan, sehingga bagi perusahaan yang belum atau tidak memenuhi standard yang sudah ditetapkan dapat dikenakan sanksi. Perihal perlindungan upah diatur dalam peraturan pemerintah Nomor 8 Tahun 1981, antara lain mengatur tentang upah yang diterima oleh para pekerja apabila pekerja sakit, halangan atau kesusahan. Disamping itu diatur pula tentang larangan diskriminasi antara tenaga kerja laki laki dan tenaga kerja wanita didalam hal menetapkan upah untuk pekerjaan yang sama nilainya. ${ }^{15}$

6) Pengaturan Istirahat / Cuti Tahunan

Bagi tenaga kerja yang sudah memiliki masa kerja 12 bulan berturut- turut berhak untuk mendapat istirahat/ cuti tahunan. Hal ini diatur dalam UndangUndang Nomor 1 Tahun 1951 Pasal 14 Peraturan Pemerintah Nomor 21 Tahun 1954 dan diperluas dengan Surat Keputusan Menteri Tenaga Kerja dan Transmigrasi Nomor 69/ MEN/80 tentang perluasan lingkungan istirahat tahunan bagi buruh.

Dalam Pasal 14 disebutkan bahwa :

- Setelah waktu istirahat seperti tersebut dalam pasal 10 dan 13 buruh menjalankan pekerjaan untuk satu atau beberapa majikan dari sautu organisasi harus diberi izin untuk beristirahat sedikit-dikitnya dua minggu tiap tahun;

\footnotetext{
${ }^{14}$ Kalsum, “Tenaga Kerja Wanita Dan Perlindungan” (Universitas Sumatera Utara, 2001), hlm. 5 .

${ }^{15}$ Kalsum, hlm. 3.
} 
- Pemberian waktu istirahat tersebut disesuaikan dengan jumlah hari masuk kerja selama satu tahun. ${ }^{16}$

c. Perlindungan yang Bersifat Kolektif

Undang-Undang Nomor 13 Tahun 2013 Pasal 176. Pelaksanaan pengawasan terdiri dari beberapa rangkaian kegiatan, meliputi:

1) Penyusunan rencana kerja

2) Pemeriksaan di perusahaan atau tempat kerja

3) Penindakan preventif maupun secara represif

4) Pelaporan hasil pemeriksaan

d. Perlindungan yang bersifat non-diskriminatif

Dengan dikeluarkannya Undang-Undang Nomor 7 Tahun 1984 tentang pengesahan Konvensi PBB mengenai penghapusan segala bentuk diskriminasi terhadap perempuan, maka penegasan perlindungan pekerja/buruh perempuan dari perilaku diskriminatif.

Berdasarkan Analisis Penulis terhadap wawancara dengan Jatmiko selaku Pimpinan Hotel Mandarin Lee Bandar Jaya Lampung Tengah, analisis penulis bahwa secara garis besar perlindungan preventif bagi tenaga kerja perempuan yang bekerja di Hotel Mandarin Lee Bandar Jaya Lampung Tengah ialah:

1) Perlindungan ekonomis, yaitu perlindungan tenaga kerja dalam bentuk penghasilan yang cukup termasuk bila tenaga kerja tidak mampu bekerja diluar kehendaknya (misalnya karena sakit, melahirkan dan lain sebagainya) yang bersangkutan tetap diberikan upah, tunjangan tetap dan tunjangan tidak tetap sebagaimana ketentuan yang berlaku.

2) Perlindungan social, yaitu perlindungan tenaga kerja dalam bentuk jaminan kesehatan kerja, pemberian Jaminan Sosial Tenaga Kerja (Jamsostek) yang meliputi jaminan kecelakaan kerja, jaminan kematian, dan jaminan pemeliharaan kesehatan;

3) Perlindungan teknis, yaitu perlindungan tenaga kerja dalam bentuk keamanan dan keselamatan kerja dari bahaya kecelakaan yang

\footnotetext{
${ }^{16}$ Kalsum.
} 
ditimbulkan oleh alat kerja, bahan yang diolah atau dikerjakan perusahaan, misalnya Program Jaminan Sosial Tenaga Kerja yang sekarang menjadi BPJS Ketenagakerjaan.

Untuk mengetahui mengenai pelaksanaan perlindungan hukum terhadap tenaga kerja, tentunya harus dilihat dari dari pelaksanaan hak-hak dan kewajiban yang timbul dalam hubungan kerja antara buruh dengan pengusaha sebagaimana yang telah ditentukan di dalam undang-undang ketenagakerjaan. Jika hak-hak dan kewajiban tersebut dapat dilaksanakan dengan baik oleh kedua belah pihak, terutama oleh pihak pengusaha, maka perlindungan terhadap tenaga kerja sudag dapat dikatakandilaksanakan dengan baik, jika tidak, berarti perlindungan tenaga kerja belum dilaksanakan.

2. Faktor Penghambat Implementasi Hukum terhadap Tenaga Kerja Perempuan yang Bekerja pada Malam Hari di Hotel Mandarin Lee Bandar Jaya

Adapun hambatan-hambatan tersebut adalah sebegai berikut:

a) Minimnya anggaran dana

b) Kurangnya Pemahaman Tenaga Kerja terhadap ketentuan peraturan perundang-undangan

c) Pekerja wanita menjalin hubungan dengan Customer

d) Lemahnya pengawasan dari Dinas Tenaga Kerja dan Transmigrasi

Hambatan-hambatan yang dihadapi dalam pelaksanaan perlindungan hukum terhadap pekerja wanita adalah adanya kesepakatan antara pekerja dengan pengusaha yang kadang menyimpang dari aturan yang berlaku, tidak adanya sanksi dari peraturan perundangan terhadap pelanggaran yang terjadi, faktor pekerja sendiri yang tidak menggunakan haknya dengan alasan ekonomi.

Agar langkah ini dapat efektif maka negara harus menjabarkannya dan mengusahakan untuk jabaran tersebut ke dala rumusan undang-undang negara dan menegakkannya dengan cara mengajukan para pelanggannya ke muka sidang pengadilan. Namun demikian, perempuan sendiri masih belum banyak yang sadar bahwa hak-haknya dilindungi dan bahwa hal tersebut mempunyai pengaruh terhadap kehidupan perempuan. 
ICEDAW (International Convention on Elimination of All Forms of Discrimination Against Women) memerintahkan kepada seluruh negara di dunia untuk tidak melakukan diskriminasi terhadap perempuan. Di dalam ICEDAW ditentukan bahwa diskriminasi terhadap perempuan adalah perlakuan yang berbeda berdasarkan gender yaitu:

a) Secara sengaja atau tidak sengaja merugikan perempuan;

b) Mencegah masyarakat secara keseluruhan memberi pengakuan terhadap hak perempuan baik di dalam maupun di luar negeri; atau

c) Mencegah kaum perempuan menggunakan hak asasi manusia dan kebebasan dasar yang dimilikinya.

Perempuan mempunyai atas perlindungan yang khusus sesuaidengan fungsi reproduksinya sebagaimana diatur pada pasal 11 ayat (1) ICEDAW huruf $\mathrm{f}$ bahwa hak atas perlindungan kesehatan dan keselamatan kerja termasuk usaha perlindungan terhadap fungsi reproduksi.

Selain itu seringkali adanya pemalsuan dokumen seperti nama, usia, alamat dan nama majikan sering berbeda dengan yang tercantum di dalam paspor. Tenaga kerja yang tidak berdokumen tidak diberikan dokumen perjanjian kerja. Hal ini juga sering terjadi pada pekerja perempuan yang bekerja di luar negeri. Maka untuk itu ICEDAW pada pasal 15 ayat (3) mengatur yaitu negara-negara peserta bersepakat bahwa semua kontrak dan semua dokumen yang mempunyai kekuatan hukum, yang ditujukan kepada pembatasan kecakapan hukum para wanita, wajib dianggap batal dan tidak berlaku.

Berdasarkan hasil penelitian penulis terhadap perlindungan hukum terhadap tenaga kerja perempuan yang bekerja pada malam hari di Hotel Mandarin Lee Bandar Jaya Lampung Tengah bahwa tenaga kerja wanita merupakan bagian dari tenaga kerja yang telah melakukan kerja baik untuk diri sendiri maupun bekerja dalam hubungan kerja atau dibawah perintah pemberi kerja (pengusaha, badan hukum atau badan-badan lainnya). Mengingat tenaga kerja wanita sebagai pihak yang lemah dari majikannya, atasannya yang kedudukannya lebih kuat, maka perlu mendapatkan perlindungan atas hak-haknya. 
Adapun pelaksanaan perlindungan hukum terhadap tenaga kerja perempuan yang bekerja pada malam hari di Hotel Mandarin Lee Bandar Jaya Lampung Tengah berpedoman pada ketentuan Undang-Undang No. 13 Tahun 2003 Tentang Ketenagakerjaan, yaitu perlindungan berupa:

1) Bidang reproduksi, meliputi :

- Hak atas cuti haid

- Hak atas cuti hamil dan keguguran

- Hak atas pemberian kesempatan menyusui

2) Bidang kesehatan dan keselamatan kerja, meliputi:

- Hak atas makanan dan minuman yang bergizi bagi pekerja perempuan yang bekerja pukul 23.00 WIB sampai dengan 07.00 WIB

- Hak atas penyediaan angkutan antar jemput bagi pekerja perempuan yang berangkat dan pulang antara pukul 23.00 WI sampai dengan pukul 05.00 WIB.

3) Bidang kehormatan perempuan, meliputi :

- Penyediaan petugas keamanan

- Penyediaan WC yang layak dengan penerangan yang memadai dan dipisah antara laki-laki dan perempuan.

Akan tetapi menurut analisi penulis bahwa pemahaman terhadap peraturan perundang-undangan yang mengatur tentang perlindungan terhadap perempuan terutama yang bekerja pada malam hari di Hotel Mandarin Lee Bandar Jaya Lampung Tengah masih sangat rendah. Rendahnya pemahaman hukum bagi para pihak ini disebabkan karena kurangnya informasi yang diperoleh tentang isi peraturan perundang-undangan tersebut sangat minim, hal ini disebabkan juga karena sumber pemberi informasi tidak mendukung sosialisasi tentang perlindungan hukum terkait dengan hak-hak asasi perempuan.

Sedangkan faktor penghambat tenaga kerja perempuan yang bekerja pada malam hari di Hotel Mandarin Lee Bandar Jaya Lampung Tengah pada dasarnya tidak ada faktor penghambat dalam pelaksanaan perlindungannya, tetapi fakta dilapangan ada pekerja yang kurang memperhatikan tata kerja yang baik sesuai 
dengan prosedur yang ada meski hal tersebut jarang terjadi, serta tingkat pendidikan pekerja yang rendah sehingga mereka tidak mengetahui tentang hakhak mereka yang seharusnya diperoleh.

\section{Penutup}

Berdasarkan analisis hasil penelitian dan pembahasan dapat disimpulkan bahwa perlindungan kerja bertujuan untuk menjamin berlangsungnya sistem hubungan kerja tanpa disertai adanya tekanan dari pihak yang kuat kepada pihak yang lemah. Perlindungan tenaga kerja bagi perempuan meliputi :

1) Perlindungan jam kerja

2) Perlindungan yang bersifat protektif

a. Peraturan cuti haid

b. Peraturan cuti hamil/ cuti bersalin/ cuti keguguran

c. Kesempatan menyusui anak

d. Penghapusab perbedaan perlakuan terhadap pekerja atau buruh perempuan

e. Jaminan sosial dan pengupahan

f. Pengaturan istirahat atau cuti tahunan

3) Perlindungan yang bersifat kolektif

4) Perlindungan yang bersifat non-diskriminatif

Hambatan- hambatan yang dihadapi dalam pelaksanaan perlindungan hukum terhadap pekerja wanita adalah adanya kesepatan antar pekerja dengan pengusaha yang kadang menyimpang dari aturan yang berlaku tidak adanya sanksi dari peraturan perundangan terhadap pelanggaran yang terjadi, faktor pekerja sendiri yang tidak menggunakan haknya dengan alasan ekonomi.

Sampai sejauh ini ketentuan yang mengatur tentang perlindungan pekerja wanita belum berjalan dengan baik. Padahal Undang-undang yang mengatur tentang perlindungan pekerja wanita sudah banyak baik itu yang bersifat nasional maupun internasional. Banyak sekali terjadi diskriminasi dan hambatan-hambatan yang terjadi pada pekerja perempuan . Hambatan-hambatan yang dihadapi dalam pelaksanaan perlindungan hukum terhadap pekerja wanita adalah adanya 
kesepakatan antara pekerja dengan pengusaha yang kadang menyimpang dari aturan yang berlaku, tidak adanya sanksi dari peraturan perundangan terhadap pelanggaran yang terjadi, faktor pekerja sendiri yang tidak menggunakan haknya dengan alasan ekonomi. Seharusnya pemerintah lebih memperhatikan masalah ini karena di jaman sekarang ini wanita memiliki kedudukan yang setara dengan lakilaki . Kemudian pemerintah juga harus tegas dalam mengatur peraturan tentang umur minimal untuk dapat bekerja bagi perempuan, karena masih banyak sekali ditemukan para pekerja wanita yang masih berusia dibawah umur minimal untuk dapat bekerja.

\section{Daftar Pustaka}

Adisiswanto, $\mathrm{Hj}$. Erwien. "Perlindungan Terhadap Tenaga Kerja Wanita Yang Bekerja Pada Malam Hari Di Perusahaan.” IUS 3, no. 01 (2015): 69-75.

Asyahadie, Zaeni. Hukum Kerja. Jakarta: PT. Rajagrafindo Persada, 2007.

Husni, Lalu. Pengantar Hukum Ketenagakerjaan Indonesia. Jakarta: PT. Rajagrafindo Persada, 2007.

Jayantari, Ni Wayan Mega. "Perlindungan Hukum Terhadap Pekerja Perempuan Pada Malam Hari Di Minimarket Alfamart Mataram (Studi Berdasarkan Undang-Undang No.13 Tahun 2003 Tentang Ketenagakerjaan." Universitas Mataram, 2013.

Kalsum. "Tenaga Kerja Wanita Dan Perlindungan.” Universitas Sumatera Utara, 2001.

Marzuki, Peter Mahmud. Penelitian Hukum. Cet. 7. Jakarta: Kencana, 2011.

Oktaviani, Prisca. "Perlindungan Pekerja Perempuan Berdasarkan UndangUndang Nomor 13 Tahun 2003 Tentang Ketenagakerjaan.” Lampung, 2013.

Petrus, Ngajulu. "Perlindungan Hukum Terhadap Tenaga Kerja Wanita Yang Bekerja Pada Malam Hari Di PT Swara Indah Riau Berdasarkan UndangUndang Nomor 13 Tahun 2003 Tentang Ketenagakerjaan.” JOM Fakultas Hukum III, no. 2 (2016): 1-15.

Prajnaparamita, Kanyaka. "Perlindungan Hukum Terhadap Tenaga Kerja Wanita Di Indomaret Kota Pekanbaru Berdasarkan Undang-Undang Nomor 13 Tahun 2003 Tentang Ketenagakerjaan.” Adminitrative Law \& Governance Journal 2, no. 1 (2019): 34-46.

Ramadhan, Rizki. "Implementasi Perlindungan Hukum Terhadap Tenaga Kerja Wanita Yang Bekerja Di SPBU Pada Malam Hari Ditinjau Dari Pasal 76 Undang-Undang Ketenagakerjaan (Studi SPBU Kabupaten Trenggalek).” Universitas Muhammadiyah Malang, 2019.

Yulianti, Dhea. "Pelaksanaan Hak-Hak Normatif Terhadap Pekerja/Buruh Perempuan Yang Bekerja Di Malam Hari Dihubungkan Dengan Keputusan Menteri Tenaga Kerja Dan Transmigrasi Republik Indonesia Nomor: Kep.224/Men/2003 Tentang Kewajiban Pengusaha Yang Mempekerjakan 
Pekerja/B.” Universitas Islam Negeri Sunan Gunung Djati Bandung, 2021. 